\title{
(2) OPEN ACCESS \\ EULAR recommendations for a core data set for pregnancy registries in rheumatology
}

\author{
Yvette Meissner (1) , ${ }^{1}$ Rebecca Fischer-Betz, ${ }^{2}$ Laura Andreoli 지, 3,4 \\ Nathalie Costedoat-Chalumeau (1) , 5 Diederik De Cock, ${ }^{7}$ Radboud J E M Dolhain, ${ }^{8}$ \\ Frauke Forger, ${ }^{9}$ Doreen Goll, ${ }^{10}$ Anna Molto $\odot{ }^{1},{ }^{11,12}$ Catherine Nelson-Piercy, ${ }_{1}^{13,14}$ \\ Rebecca Özdemir, ${ }^{15}$ Luigi Raio, ${ }^{16}$ Sebastian Cruz Rodríguez-García ำ ${ }_{1}^{17}$ \\ Savino Sciascia (1) ${ }^{18}$ Marianne Wallenius, ${ }^{19,20}$ Astrid Zbinden, ${ }^{9}$ Angela Zink, ${ }^{1}$ \\ Anja Strangfeld (ㄱ) ${ }^{1}$
}

\section{Handling editor Josef $S$ Smolen \\ - Additional material is published online only. To view please visit the journal online (http://dx.doi.org/10.1136/ annrheumdis-2020-218356)}

For numbered affiliations see end of article.

\section{Correspondence to} Ms Yvette Meissner, Epidemiology and Health Care Research, German Rheumatism Research Center Berlin, Berlin,

Berlin, Germany;

y.meissner@drfz.de

YM and RF-B are joint first authors.

Part of this work was presented at the EULAR Annual Conference 2019 (Meissner et al, Ann Rheum Dis. 2019; 78 (Suppl 2): 246-246).

Received 18 June 2020 Revised 1 September 2020 Accepted 7 September 2020 Published Online First 14 October 2020

\section{ABSTRACT}

Background and objective There is an urgent need for robust data on the trajectories and outcomes of pregnancies in women with inflammatory rheumatic diseases (IRD). In particular when rare outcomes or rare diseases are to be investigated, collaborative approaches are required. However, joint data analyses are often limited by the heterogeneity of the different data sources. To facilitate future research collaboration, a European League Against Rheumatism (EULAR) Task Force defined a core data set with a minimum of items to be collected by pregnancy registries in rheumatology covering the period of pregnancy and the 28-day neonatal phase in women with any underlying IRD.

Methods A stepwise process included a two-round Delphi survey and a face-to-face meeting to achieve consensus about relevant items.

Results A total of 64 multidisciplinary stakeholders from 14 different countries participated in the two rounds of the Delphi process. During the following face-to-face meeting of the EULAR Task Force, consensus was reached on 51 main items covering 'maternal information', 'pregnancy' and 'treatment'. Generic instruments for assessment are recommended for every item. Furthermore, for the five most frequent IRDs rheumatoid arthritis, spondyloarthritis, juvenile idiopathic arthritis, systemic lupus erythematosus and other connective tissue diseases, disease-specific laboratory markers and disease activity measurements are proposed.

Conclusion This is the first consensus-based core data set for prospective pregnancy registries in rheumatology. Its purpose is to stimulate and facilitate multinational collaborations that aim to increase the knowledge about pregnancy course and safety of treatment in women with IRDs during pregnancy.

\section{Check for updates}

(c) Author(s) (or their employer(s)) 2021. Re-use permitted under CC BY-NC. No commercial re-use. See rights and permissions. Published by BMJ.

To cite: Meissner $Y$, Fischer-Betz R, Andreoli L, et al. Ann Rheum Dis 2021:80:49-56.

\section{INTRODUCTION}

In recent years, several European pregnancy registries have been established in rheumatology to prospectively collect and analyse data on pregnant women with different inflammatory rheumatic diseases (IRD). However, certain research issues, for example, studying the pregnancy course in rare diseases, require even larger study populations, often exceeding the number of patients available in each registry, making collaborative analyses desirable. The European League Against Rheumatism (EULAR) Task Force on antirheumatic drugs during pregnancy and lactation ${ }^{1}$ also highlighted the need for collaboration to collate data on newer medications.

Combined analysis of data from different sources requires a certain degree of homogeneity among the data collected. A recent comprehensive survey of four registries working together in the European Network of Pregnancy Registries in Rheumatology (EuNeP) showed similar study designs in terms of prospective data collection, inclusion of patients with IRD before or during early pregnancy, and reporting of data in each trimester of pregnancy. ${ }^{2}$ However, major differences were found in the details of data collection, for example, in the instruments used to measure disease activity. As highlighted by other initiatives in rheumatology, harmonising and standardising items and their measurement across studies is critical to facilitate collaborative research. ${ }^{3-6}$

A EULAR Task Force was therefore convened to define a core data set for registries and observational studies that prospectively collect information about pregnant women with IRD including the neonatal phase (fourweeks post partum). The core set was developed to encompass a minimum of standardised items to be collected paving the way for multinational collaborations.

\section{METHODS}

An iterative process according to EULAR standardised operating procedures was applied to develop the core set. ${ }^{7}$ The Task Force comprised a convenor (AS) and coconvenor (RFB), a methodologist (AZi), a fellow (YM), eight Task Force members (LA, NC-C, RJEMD, FF, AM, CN-P, LR, MW), three EMEUNET members (DDC, SCRG, SS), two patient research partners (DG, RÖ) and one health professional (AZb). The scope and core areas of the core set according to the Core Outcome Set-STAndards for Development recommendations were defined by consensus. ${ }^{8}$ A study protocol was developed and circulated among the Task Force. The flow chart gives an overview of all steps taken during the project (figure 1).

\section{Generation of items}

Items estimated relevant to be included in the core set were compiled (1) by a systematic literature 


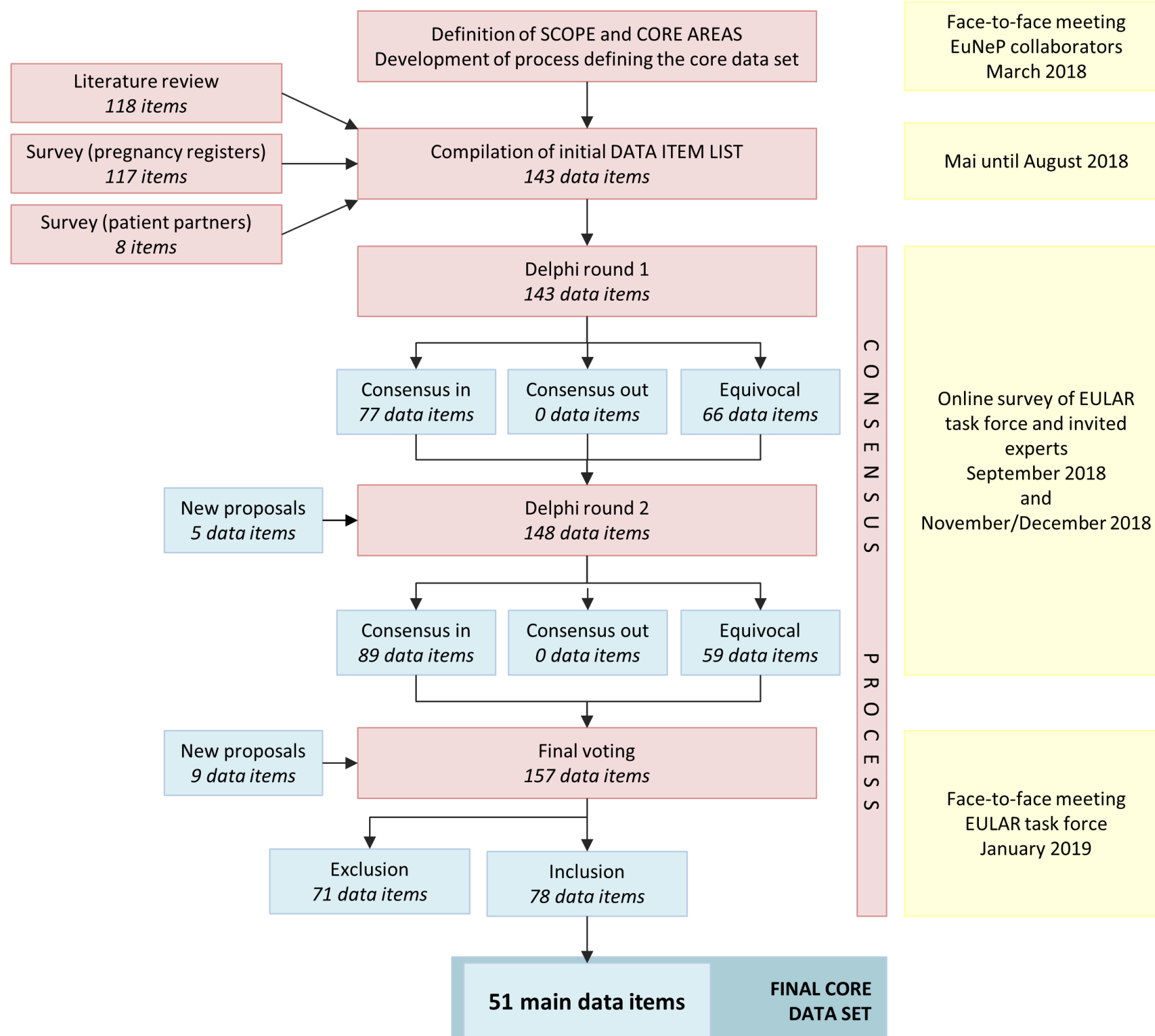

Figure 1 Flow chart of the development and consensus process for the core data set. EULAR, European League Against Rheumatism; EuNeP, European Network of Pregnancy Registries in Rheumatology

search (see online supplemental for details) and underpinned (2) by an inventory of items collected by registries participating in $\mathrm{EuNeP}^{2}$ and (3) from results of a survey among three EuNeP patient representatives regarding their needs during pregnancy. An initial list of items was created by deleting duplicates, grouping similar items and refinement. Consequently, every item on the list was assigned to its respective core area.

Consensus process, outcome scoring and consensus definition The importance of each item for the final core set was judged by a stepwise consensus process encompassing a two-round Delphi survey and a final vote. In addition to the members of the EULAR Task Force (except the fellow), additional experts in the field of pregnancy and rheumatology from different European countries were invited to participate during the Delphi votes. In particular, up to five clinicians involved in each of the four registries of the EuNeP collaboration, as well as clinical researchers and experts in the areas of rheumatology, epidemiology, obstetrics, gynaecology, internal medicine as well as other health professionals were directly invited by email. The Delphi process was performed using the online tool 'Delphi Manager' (http://www. comet-initiative.org/delphimanager/). This tool ensures the anonymity of all participants and adherence to the single steps of the Delphi process.

Participants were asked to rate the importance of each item to be included in a core set for pregnancy registries in rheumatology using the Grading of Recommendations, Assessment, Development and Evaluations scale ${ }^{9}$ from 1 to $9(1-3=$ not important, 4-6=importantbut not critical, 7-9=critical/very important). The participants had the option to indicate an item as 'unable to score' if necessary and could give comments on each item. Additionally, adding comments at the end of the survey was also possible. The scores of every participant were anonymous throughout the survey. Finally, participants were asked to suggest additional items that were not listed in the initial item list. All suggested, additional items were thoroughly reviewed by nine 


\begin{tabular}{|c|c|c|}
\hline Decision & Definition & Explanation \\
\hline \multicolumn{3}{|l|}{ Delphi round 1/2 } \\
\hline Consensus in & $\begin{array}{l}\geq 70 \% \text { of the participants } \\
\text { rated the item as critically } \\
\text { important for the core data } \\
\text { set (scores } 7-9 \text { ) }\end{array}$ & $\begin{array}{l}\text { Item will be included into the } \\
\text { final core data set }\end{array}$ \\
\hline Consensus out & $\begin{array}{l}\geq 70 \% \text { of the participants } \\
\text { rated the item as not } \\
\text { important for the core data } \\
\text { set (scores } 1-3 \text { ) }\end{array}$ & $\begin{array}{l}\text { Item will be excluded from } \\
\text { the final core data set }\end{array}$ \\
\hline Equivocal & $\begin{array}{l}\text { All items that are neither } \\
\text { in the consensus-in nor in } \\
\text { the consensus-out group }\end{array}$ & $\begin{array}{l}\text { No consensus was reached } \\
\text { for the respective item. Final } \\
\text { decision at the consensus } \\
\text { meeting }\end{array}$ \\
\hline \multicolumn{3}{|c|}{ Face-to-face consensus meeting } \\
\hline Consensus in & $\begin{array}{l}\text { Simple majority (>50\% } \\
\text { of votes) }\end{array}$ & $\begin{array}{l}\text { Item will be included into the } \\
\text { final core data set }\end{array}$ \\
\hline Consensus out & $\begin{array}{l}\text { Simple majority (>50\% } \\
\text { of votes) }\end{array}$ & $\begin{array}{l}\text { Item will be excluded from } \\
\text { the final core data set }\end{array}$ \\
\hline
\end{tabular}

members of the Task Force, and eligible items were added in Delphi round 2.

Every participant of Delphi round 1 was invited to rescore the items in round 2 taking total scoring results (given as percentages of all participants scoring 1-9) and their own scores of round 1 into account. Each Delphi round had to be completed within 3 weeks. After completion of both Delphi rounds, scores of round 2 were summarised and assigned to one of the three pre-specified consensus definitions comprising 'consensus in', 'consensus out' and 'equivocal' (table 1) according to OMERACT recommendations. ${ }^{10}$

All items that neither reached 'consensus in' nor 'consensus out' were defined as equivocal and needed a final voting. The final voting took place at a face-to-face consensus meeting of the EULAR Task Force. During this meeting the items were discussed and finally voted on. The voting was conducted via a mobile phone based electronic voting system (www.tedme.com). Items that reached a majority of votes were included into the core set, those with a majority of negative votes were excluded. Furthermore, the Task Force refined the core set and discussed all items with 'consensus-in' status regarding their applicability in a core set and usefulness for research purposes. Of note, the way of assessment of each item and their exact definition was not subject of the Delphi voting.

Since the core set is supposed to cover items important for a variety of IRDs, it was strengthened during the Task Force meeting to also define additional, disease-specific items covering laboratory markers as well as disease activity and damage measurements. All relevant items were summarised by the Task Force and the importance of each item for the respective disease was rated in a written non-anonymous voting. Each Task Force member made her/his decisions according to her/his expertise in the field. Items that reached a majority of positive votes were included in the additional item list. The additional items were defined for the most prevalent IRDs in women of reproductive age: rheumatoid arthritis, spondyloarthritis, juvenile idiopathic arthritis, systemic lupus erythematosus and other connective tissue diseases. Other connective tissue diseases include Sjögren's syndrome, undifferentiated connective tissue disease, scleroderma, myositis and mixed connective tissue diseases.

\section{Data analysis}

For both Delphi rounds, mean and SD, median, minimum and maximum as well as the distribution of scores within the three consensus categories were calculated using SAS software V.9.4.

\section{RESULTS}

\section{Stakeholders}

In total, 73 experts received an email invitation to participate in the Delphi vote, including 17 members of the EULAR Task Force. Of all experts invited, 65 (89\%) participated in round 1 and $64(88 \%)$ in round 2 . About two-thirds of the experts (69\%) participating in both Delphi rounds were women. The majority of participants $(81 \%)$ had 10 years or more work experience, $14 \%$ were working for at least 5 and up to 10 years, and $5 \%$ indicated 5 years or less work experience. A total of $84 \%$ were rheumatologists, $5 \%$ each were obstetricians and epidemiologists, $3 \%$ each patients and midwives. Experts from 14 different European countries were represented (online supplemental table 1 shows country distribution).

\section{Definition of core areas}

Three core areas were defined as 'maternal information', 'pregnancy' and 'treatment' (figure 2). 'Maternal information' includes the core domains demographics and risk behaviours, disease characteristics of the underlying IRD and prevalent comorbidities. The core area 'pregnancy' encompasses information on obstetrical history, the course, outcomes and delivery of the current pregnancy and outcomes of the neonate. In the core area 'treatment', medical treatment within 12 months prior to conception, the treatment of the IRD during pregnancy and post partum as well as the use of other treatments during pregnancy are subsumed.

\section{Results of the consensus process for non-disease specific items}

A total of 143 items were up for voting in Delphi round 1. Of those, 77 items were voted as critically important by at least $70 \%$ of the participants. Another 69 new items were suggested to be added to the following Delphi round. All of them were thoroughly reviewed by eight members of the Task Force, and five items were considered as new and relevant for the item list (online supplemental table 2). They encompass gestational age at birth in previous pregnancies, number of previous miscarriages, neonatal infections, the use of non-steroidal anti-inflammatory drugs (NSAIDs) and start and stop dates of NSAID treatment.

With the newly suggested items of round 1, Delphi round 2 included a total of 148 items. Of those, 89 items reached consensus in during the vote, none of the items reached consensus out and 59 items were rated as equivocal and were therefore neither in nor excluded (figure 1, online supplemental table 3).

At a face to face meeting of the Task Force members $(n=12)$, all equivocal items were voted on. Task Force members who were unable to attend the meeting $(n=5)$ received the voting list in advance and their votes were incorporated into the decision process. Additionally, participants of the meeting discussed and evaluated all items of the final core set with respect to the importance of the item for research purposes and redundancy. All decisions are explained in detail in online supplemental table 3. In order to make the extensive list of the resulting 78 included items more comprehensible for the user, the items were consequently defined as either main item $(n=51)$ or operationalizing item $(n=27)$. Items of the final core set are presented in table 2 . Furthermore, the way of assessment/operationalisation for each 


\begin{tabular}{|c|c|c|}
\hline Maternal information & Pregnancy & Treatment \\
\hline $\begin{array}{l}\text { Demographics and } \\
\text { risk behaviours } \\
\text { IRD disease characteristics } \\
\text { Prevalent } \\
\text { comorbidities }\end{array}$ & $\begin{array}{c}\text { Obstetrical history } \\
\text { Course of current } \\
\text { pregnancy } \\
\text { Delivery/ outcome of the } \\
\text { current pregnancy } \\
\text { Neonatal outcomes }\end{array}$ & $\begin{array}{l}\text { Treatment } 12 \text { months prior } \\
\text { to conception } \\
\text { IRD treatment during } \\
\text { pregnancy and postpartum } \\
\text { Use of other treatments } \\
\text { during pregnancy }\end{array}$ \\
\hline
\end{tabular}

Figure 2 Core areas for the core data set for pregnancy registries in rheumatology. IRD, inflammatory rheumatic disease.

main item including instruments and categories where appropriate was defined and summarised in the online supplemental table 4.

\section{Recommendations for disease-specific items}

The recommended laboratory markers and disease activity measurements found to be relevant by the Task Force for the five IRDs rheumatoid arthritis, spondyloarthritis, juvenile idiopathic arthritis, systemic lupus erythematosus and other connective tissue diseases are presented in table 3 . It is recommended for registers to collect the single components of a summary score rather than only the score, for example, $\mathrm{C}$ reactive protein (CRP), 28 swollen and tender joint count (SJC, TJC) rather than collecting only the disease activity score Disease Activity Score based on 28 tender and swollen joints and $\mathrm{C}$ reactive protein.

\section{Methodological considerations}

Pregnancy registries are prospective observational cohort studies that collect essential clinical information related to pregnancy in order to improve the safety of mother and child. The items defined with this core set refer to women with IRD and cover the pregnancy and the neonatal phase. The Task Force recommends that patients should be enrolled at the earliest possible point in time during pregnancy. Data should ideally be collected once every trimester and during the neonatal phase (within 28 days after birth). Besides the collection of items and their operationalisation, the visit date of every documented encounter between patient and physician should be reported. In addition, each registry must define, prior to its start, those diagnoses that shall be covered by the study.

\section{DISCUSSION}

We present the first consensus-based core data set for pregnancy registries in rheumatology. The comprehensive list of 51 main items should be uniformly collected by all pregnancy registries in rheumatology to ensure homogeneity and comparability of data and to enable joint utilisation of different data sources.

To date, no such recommendations for pregnancy registries in rheumatology are available even though the need has been highlighted previously. ${ }^{11}$ In the absence of common standards, published pregnancy studies in rheumatology are highly heterogeneous, leading to partly controversial results ${ }^{12}$ or noncomparable information. ${ }^{13}$ In 2008 , Schaefer et al summarised the objectives of pregnancy studies based on data of Teratology Information Services (TIS) and explained how they document and evaluate drug effects on pregnancy. ${ }^{14}$ Although most of the variables are also essential for pregnancy registries in rheumatology,
TIS are not tailored to patients with IRD. Since the chronic disease itself can affect the pregnancy and its outcomes, ${ }^{15}$ it is essential to collect specific information on the disease course of IRD by registries and observational cohorts.

Recently, Vinet et al compiled basic lists with variables to be collected by rheumatic pregnancy registries focusing on the most important information needed to answer questions about disease activity, medication use and pregnancy outcome. ${ }^{16}$ Many variables correspond to the herein proposed core set. However, this core set goes beyond the list of desirable information and makes recommendations on how and in what way the information should be collected in order to harmonise different data sources. In addition, the Task Force has summarised diseasespecific parameters that are essential for assessing the course and severity of the IRD. Further differences can be found in methodological aspects. Vinet and colleagues followed an individual approach representing their (North American) views, while the core set is based on a structured consensus process following the methodology for EULAR recommendations. A variety of European experts in the field as well as patient representatives were involved. Registry holders and users were able to incorporate their experience into the different steps of the voting process, and the Task Force has taken the feasibility of implementing the core set in everyday clinical practice in different countries into account. International acceptance therefore can be expected to be high.

This EULAR endorsed core set represents clinically relevant and feasible parameters that are critical for scientific research, especially with a focus on multinational collaborations. The challenge of the stepwise consensus process was to select the most relevant items regarding maternal information and the rheumatic disease as well as pregnancy and neonatal outcomes. This explains the inclusion of 51 items, which is-in comparison to other core sets in rheumatology ${ }^{3-5}$ or core sets with relation to maternal and new-born's health ${ }^{17}$ — quite an extensive list.

The core set is a compromise between scientific purposes and research interests on the one hand and the feasibility for rheumatologists and other physicians or study nurses that document data from daily care on the other hand. We are for example aware of the importance of recording intrauterine growth restriction (IUGR) to differentiate between infants born small for gestational age (SGA) into those with a steady foetal development in rather lower percentiles of the growth curves versus those foetuses that first develop normally and then experience a sudden growth disturbance. However, we presume that information on IUGR may either be not available for many pregnancies or-since IUGR and SGA are often used interchangeably-their 
Table 2 Main items of the final core data set for pregnancy registries in rheumatology and their operationalisation and instruments for assessment

\begin{tabular}{lll}
\hline No. Main items & $\begin{array}{l}\text { Operationalisation/instruments for } \\
\text { assessment }\end{array}$
\end{tabular}

\begin{tabular}{lll} 
No. & Main items & assessment \\
\hline \multicolumn{2}{l}{ Maternal information } & \\
Demographics and risk behaviours & \\
1 & Age & Date of birth or month/year of birth \\
2 & Height & $\mathrm{cm}$ \\
3 & $\begin{array}{l}\text { Weight before (or in } \\
\text { early) pregnancy }\end{array}$ & $\mathrm{kg}$ \\
4 & Educational level & $\begin{array}{l}\text { Highest educational level according } \\
\text { to national standards or/total years of } \\
\text { completed education } \\
\text { Categorisation: yes/no }\end{array}$ \\
\hline 5 & $\begin{array}{l}\text { Alcohol consumption } \\
\text { during pregnancy }\end{array}$ & $\begin{array}{l}\text { Categorisation: yes/no } \\
\text { Smoking during } \\
\text { pregnancy }\end{array}$ \\
\hline
\end{tabular}

IRD disease characteristic

\begin{tabular}{|c|c|c|}
\hline 7 & IRD diagnosis & Physician reported clinical diagnosis* \\
\hline 8 & Classification criteria & Indication, which criteria are fulfilled \\
\hline 9 & Disease duration & Month/year or year of diagnosis \\
\hline 10 & $\begin{array}{l}\text { Physician reported IRD } \\
\text { severity }\end{array}$ & NRS or VAS \\
\hline 11 & Auto-antibodies $\dagger$ & $\begin{array}{l}\text { See additional recommendations } \\
\text { (table 3) }\end{array}$ \\
\hline 12 & Physician reported flares & $\begin{array}{l}\text { Assessment of (1) yes/no; (2) number } \\
\text { of flares }\end{array}$ \\
\hline 13 & $\begin{array}{l}\text { Physician reported } \\
\text { disease activity }\end{array}$ & NRS or VAS \\
\hline 14 & Disease activity by score $\dagger$ & $\begin{array}{l}\text { See additional recommendations } \\
\text { (table 3) }\end{array}$ \\
\hline 15 & $\mathrm{C}$ reactive protein & eg, mg/L \\
\hline 16 & $\begin{array}{l}\text { Patient reported disease } \\
\text { activity }\end{array}$ & NRS or VAS \\
\hline 17 & $\begin{array}{l}\text { Patient reported global } \\
\text { health }\end{array}$ & NRS or VAS \\
\hline
\end{tabular}

Prevalent comorbidities

$18 \quad \begin{aligned} & \text { Selected prevalent } \\ & \text { comorbidities }\end{aligned}$

Yes/no assessment of: (1)

antiphospholipid syndrome, (2) diabetes mellitus, (3) arterial hypertension,

(4) renal disease, (5) previous

thromboembolic events

Pregnancy

Obstetrical history

\begin{tabular}{|c|c|c|}
\hline 19 & Gravidity & Number \\
\hline 20 & Parity & Number \\
\hline 21 & $\begin{array}{l}\text { Outcome of previous } \\
\text { pregnancy(ies) }\end{array}$ & $\begin{array}{l}\text { Categorised into foetal death (including } \\
\text { pregnancy loss and stillbirths)/live birth; } \\
\text { assessment of (1) number of foetal } \\
\text { deaths and live births; (2) gestational } \\
\text { age }\end{array}$ \\
\hline 22 & Preterm birth(s) & Number \\
\hline 23 & Neonatal death(s) & Number \\
\hline 24 & $\begin{array}{l}\text { Congenital } \\
\text { malformations }\end{array}$ & Free text \\
\hline 25 & $\begin{array}{l}\text { Hypertensive pregnancy } \\
\text { disorders }\end{array}$ & $\begin{array}{l}\text { Yes/no assessment of: pre-eclampsia, } \\
\text { eclampsia, HELLP syndrome }\end{array}$ \\
\hline \multicolumn{3}{|c|}{ Course of current pregnancy } \\
\hline 26 & Planned pregnancy & Yes/No \\
\hline 27 & Assisted reproduction & Yes/No \\
\hline 28 & $\begin{array}{l}\text { Estimated date of } \\
\text { conception }\end{array}$ & Day/Month/Year \\
\hline
\end{tabular}

Table 2 Continued

\begin{tabular}{|c|c|c|}
\hline No. & Main items & $\begin{array}{l}\text { Operationalisation/instruments for } \\
\text { assessment }\end{array}$ \\
\hline 29 & $\begin{array}{l}\text { Singleton } /{ }^{*} \text {-/multiple } \\
\text { pregnancy }\end{array}$ & Number of foetuses \\
\hline 30 & $\begin{array}{l}\text { Adverse events of } \\
\text { interest }\end{array}$ & $\begin{array}{l}\text { (1) Yes/no assessment of non- } \\
\text { serious and serious events of: } \\
\text { (a) gestational hypertension, (b) } \\
\text { pre-eclampsia, eclampsia, HELLP } \\
\text { syndrome, (c) gestational diabetes, (d) } \\
\text { thromboembolic events; (2) date of the } \\
\text { beginning of the event; (3) indication } \\
\text { if the event has led to hospitalisation } \\
\text { or death } \ddagger\end{array}$ \\
\hline 31 & $\begin{array}{l}\text { Other serious adverse } \\
\text { events }\end{array}$ & $\begin{array}{l}\text { Assessment of (1) the kind of event as } \\
\text { free text; ( } 2 \text { ) date of the beginning of } \\
\text { the event; (3) indication if the event has } \\
\text { led to hospitalisation or death‡ }\end{array}$ \\
\hline
\end{tabular}

Delivery/outcome of the current pregnancy

32 Elective termination Assessment of (1) yes/no; (2) gestational age; (3) reasons for termination categorised into (a) termination due to malformation, (b) termination due to other reasons

$\begin{array}{ll}33 & \text { Foetal death } \\ 34 & \text { Live birth } \\ 35 & \begin{array}{l}\text { Gestational age at } \\ \text { delivery }\end{array} \\ 36 & \begin{array}{l}\text { Preterm premature } \\ \text { rupture of membranes }\end{array} \\ 37 & \text { Mode of delivery }\end{array}$

Including pregnancy loss and stillbirths; assessment of (1) yes/no; (2) gestational age (weeks) at diagnosis

Yes/No

In weeks and days

Yes/No

(1) Categorised into spontaneous vaginal delivery/operative vaginal delivery/caesarean section (CS)/mode of delivery not specified, and in case of CS (2) reasons categorised into: elective CS/foetal reasons/maternal reasons/ combined foetal and maternal reasons/ unknown reasons

Neonatal outcomes

$\begin{array}{lll}38 & \text { Birth weight } & \begin{array}{l}\text { In kilogram with two decimal digits } \\ \text { or gram } \\ \text { Categorisation: female/male/other }\end{array} \\ 49 & \begin{array}{l}\text { Gender } \\ \text { Breast feeding }\end{array} & \begin{array}{l}\text { Categorisation: yes, for at least } 4 \text { weeks } \\ \text { after birth/no }\end{array} \\ 41 & \begin{array}{l}\text { Congenital heart block } \\ \text { Ces/No }\end{array} & \begin{array}{l}\text { Congenital } \\ \text { malformations }\end{array} \\ 42 & \begin{array}{l}\text { Fee text } \\ \text { events during the first } \\ \text { 28 days of live }\end{array} & \begin{array}{l}\text { Assessment of (1) the kind of event as } \\ \text { free text; (2) date of the beginning of } \\ \text { the event; (3) indication if the event has } \\ \text { led to hospitalisation or death }\end{array}\end{array}$

\section{Treatment}

Treatment 12 months prior to conception

$\begin{array}{lll}44 & \text { DMARD use } & \begin{array}{l}\text { Assessment of (I) yes/no; (2) name§; (3) } \\ \text { start/stop dates }\end{array} \\ 45 & \text { Oral glucocorticoid use } & \text { Yes/No } \\ 46 & \begin{array}{l}\text { Use of potentially } \\ \text { teratogenic medication }\end{array} & \text { Free text } \\ & \end{array}$

IRD treatment during pregnancy and post partum

$\begin{array}{ll}47 & \text { Assessment of (1) yes/no; (2) name§; } \\ & \text { (3) dose; (4) application intervals; } \\ & \text { (5) start/stop dates; (6) reasons for } \\ \text { discontinuation }\end{array}$

Continued 
Table 2 Continued

\begin{tabular}{lll}
\hline No. & Main items & $\begin{array}{l}\text { Operationalisation/instruments for } \\
\text { assessment }\end{array}$ \\
\hline 48 & Oral glucocorticoid use & $\begin{array}{l}\text { Assessment of (1) yes/no; (2) dose; (3) } \\
\text { application intervals; (4) start/stop dates }\end{array}$ \\
49 & $\begin{array}{l}\text { Intraarticular } \\
\text { glucocorticoid use }\end{array}$ & $\begin{array}{l}\text { Assessment of (1) yes/no; (2) date of } \\
\text { application }\end{array}$ \\
50 & NSAID use & $\begin{array}{l}\text { Assessment of (1) yes/no; (2) name; (3) } \\
\text { start/stop dates }\end{array}$ \\
Use of other treatments during pregnancy & Yes/no assessment of use of (1) \\
51 & $\begin{array}{l}\text { Use of selected } \\
\text { treatments }\end{array}$ & $\begin{array}{l}\text { (3) folic acid and (4) heparin/other } \\
\text { anticoagulants }\end{array}$ \\
\hline
\end{tabular}

Explanations of the main items are given in online supplemental table 4.

*Which diagnoses are covered by the registry, must defined in advance by every registry.

tVariables differ according to IRD diagnosis and are further defined in table 3. ¥This recommendation is based on the ICH E2A guideline. ${ }^{25}$

§For biological or targeted synthetic disease modifying antirheumatic drugs it is recommended to record the trade name.

DMARD, disease modifying anti-rheumatic drug; HELLP, complication of pregnancy characterised by haemolysis, elevated liver enzymes and a low platelet count; IRD, inflammatory rheumatic disease; NRS, Numeric Rating Scale; NSAID, non-steroidal anti-inflammatory drug; VAS, Visual Analogue Scale.

different meaning may not always be clear. We therefore decided to exclude IUGR from the core set.

The supplemental material contains descriptions and definitions for all main items as far as this is possible. Even though it would be desirable to have uniform definitions for all items, this is not feasible for various reasons. Registries can only collect data within the framework of the health system and regulatory requirements of their country of origin and therefore, countryspecific differences cannot be avoided. ${ }^{18}{ }^{19}$ For a number of items, the reporting health professional has to rely on information that is provided by obstetricians, for example, the event of pre-eclampsia. Definition and classification systems however vary and can result in discrepancies of incidence rates. ${ }^{20} 21$

The period we were focused on for these recommendations was the time of pregnancy and the 28-day postpartum period (neonatal phase). The targeted patient population are patients with IRD. Since these recommendations shall be applicable to all IRDs, the final core set encompasses non-disease specific, generic items. Furthermore, for the five most prevalent IRDs, important laboratory markers and instruments to measure disease activity and damage have been defined. Of note, the core data set encompasses only the minimum items that have been classified as essential by experts in the field. It is up to each individual registry to add further items, to ask more details for an item and/or to use additional instruments or categories beyond those that are proposed within this core set.

Our proposed core set is on one side intended to serve as a basis for evolving registries to prioritise and facilitate data collection. On the other side, the core set can be used by existing observational studies and registries to focus their data quality management on those outcomes that were found to be of high importance to facilitate collaborative analyses with other registries. This will enable the growing number of (pregnancy) registries in Europe to perform joint analyses, allowing to explore relevant aspects in more detail and with robust data.

Collecting data in different countries by applying an internationally standardised protocol offers the chance to create the world's largest source of information of pregnancies in women with IRD including drug safety. Encouraging and recruiting pregnant patients and collecting reliable data is the basis to fill current knowledge gaps and to guide IRD patients with the wish to have children in the future. Such a database can also serve as an information source for regulatory authorities and can help

Table 3 Additional items for selected diseases

\begin{tabular}{|c|c|c|}
\hline Disease & Autoantibodies/laboratory markers & $\begin{array}{l}\text { Disease activity/ } \\
\text { damage scores }\end{array}$ \\
\hline Rheumatoid arthritis & $\begin{array}{l}\text { Anti-citrullinated protein antibody (ACPA) } \\
\text { Rheumatoid factor (RF) }\end{array}$ & $\begin{array}{l}-28 \mathrm{SJC} \\
-28 \mathrm{TJC} \\
- \text { DAS28-CRP3 }\end{array}$ \\
\hline Spondyloarthritis & HLA-B27 & $\begin{array}{l}>\text { ASDAS } \\
>\text { BASDAI }\end{array}$ \\
\hline Juvenile idiopathic arthritis & $\begin{array}{l}\text { Anti-citrullinated protein antibody (ACPA) } \\
\text { Rheumatoid factor (RF) } \\
\text { Antinuclear antibodies (ANA) }\end{array}$ & $\begin{array}{l}-28 \mathrm{SJC} \\
-28 \mathrm{TJC} \\
- \text { DAS28-CRP3 }\end{array}$ \\
\hline Systemic lupus erythematosus & $\begin{array}{l}\text { Antiphospholipid antibodies (aPL), in particular: anti-cardiolipin (aCL) antibodies, } \\
\text { anti-beta-2-glycoprotein-I-antibodies, lupus anticoagulant (LA) } \\
\text { Antinuclear antibodies (ANA) } \\
\text { Anti-double-stranded DNA antibodies } \\
\text { Extractable nuclear antigen (ENA) antibodies, in particular: anti-La/SSB } \\
\text { antibodies, anti-Ro/SSA antibodies, anti-Sm antibodies, anti-U1-ribonucleoprotein } \\
\text { (RNP) antibodies } \\
\text { Serum C3/C4 }\end{array}$ & $\begin{aligned} & \text { SLEPDAI }\left(\text { SLEDAI }{ }^{*}\right) \\
& \text { SLICCIACR } \\
& \text { damage index }\end{aligned}$ \\
\hline Other connective tissue diseases & $\begin{array}{l}\text { Antiphospholipid antibodies (aPL), in particular: anti-cardiolipin (aCL) antibodies, } \\
\text { anti-beta-2-glycoprotein-I-antibodies, lupus anticoagulant (LA) } \\
\text { Extractable nuclear antigen (ENA) antibodies, in particular: anti-La/SSB } \\
\text { antibodies, anti-Ro/SSA antibodies, anti-U1-ribonucleoprotein (RNP) antibodies } \\
\text { Antinuclear antibodies (ANA) } \\
\text { Serum C3/C4 }\end{array}$ & \\
\hline
\end{tabular}

*SLEDAI instead of SLEPDAI for postpartum disease activity.

ASDAS, Ankylosing Spondylitis Disease Activity Score; BASDAI, Bath Ankylosing Spondylitis Disease Activity Index; DAS28-CRP3, Disease Activity Score based on 28 tender and swollen joints and C reactive protein; SLICCIACR Damage Index, Systemic Lupus International Collaborating Clinics/American College of Rheumatology Damage Index; SJC, swollen joint count; SLEDAI, Systemic Lupus Erythematosus Disease Activity Index; SLEPDAI, Systemic Lupus Erythematosus in Pregnancy Disease Activity Index; TJC, tender joint count. 
to establish research guidelines. With this core set, we hope to encourage other scientist to set up pregnancy registries and to collaborate in joint projects.

\section{Strengths and limitations}

The methodological strength of developing this core set is the application of robust methods with a stepwise consensus-based process $^{782223}$ involving multi-stakeholder groups, for example, experienced rheumatologists, epidemiologists, obstetricians, healthcare professionals and patients. The Delphi process is an established method for achieving consensus ${ }^{24}$ and has the advantage of maintaining the anonymity of participants. We had a low attrition rate with only one participant who did not complete both rounds. In all consensus steps, the participants were reminded that only those items that are both essentially important for joint research and feasible in daily clinical care, should be selected.

This core data set focuses on data collection during pregnancy including the outcome of pregnancy. This decision was made in order to achieve a minimal data set for the most important time period. However, information about the time before pregnancy and further observation of women and children after delivery is highly desirable in order to answer research questions like, for example, the time to pregnancy, early abortion/miscarriage rates or the development of the child beyond 4 weeks of age. We therefore recommend to extend the observation of the child beyond the time frame addressed here in order to assess longterm outcomes concerning child development. This is a gap in the current literature and should be the focus of future collaborative studies with paediatricians.

\section{CONCLUSION}

This EULAR Task Force proposes a core data set with a minimum of items to be collected by pregnancy registries in rheumatology. Our aim was to facilitate collaborative research and joint data analyses. As the design of registries may vary considerably between countries and will be influenced by the different healthcare systems, this common data set was deliberately kept short and simple, concentrating on the most important information that is needed for meaningful joint analyses. We hope that this proposal will be useful when establishing new registries and also increase the willingness of rheumatologists, other healthcare professionals and patients to contribute to the registries and provide the necessary data.

\footnotetext{
Author affiliations

${ }^{1}$ Epidemiology and Health Care Research, German Rheumatism Research Center Berlin, Berlin, Germany

${ }^{2}$ Department for Rheumatology and Hiller Research Institute, Heinrich Heine University Düsseldorf, Dusseldorf, Germany

${ }^{3}$ Department of Clinical and Experimental Sciences, University of Brescia, Brescia, Italy

${ }^{4}$ Unit of Rheumatology and Clinical Immunology, ASST Spedali Civili di Brescia, Brescia, Italy

${ }^{5}$ Internal Medicine Department, Referral Center for Rare Autoimmune and Systemic Diseases, Hospital Cochin, Paris, France

${ }^{6}$ CRESS, INSERM, INRA, Université de Paris, Paris, France

${ }^{7}$ Department of Development and Regeneration KU, KU Leuven, Leuven, Belgium

${ }^{8}$ Medical Centre, Department of Rheumatology, Erasmus University Rotterdam,

Rotterdam, Netherlands

${ }^{9}$ Department of Rheumatology, Immunology and Allergology, Inselspital University Hospital Bern, Bern, Switzerland

${ }^{10}$ Patient research partner, Berlin, Germany

${ }^{11}$ Rheumatology Department, Hospital Cochin, Paris, France

${ }^{12} \mathrm{U}-1153$, INSERM, University of Paris, Paris, France

${ }^{13}$ Obstetric Medicine Service, Queen Charlotte's and Chelsea Hospital, London, UK
}

${ }^{14}$ Department of Women and Children's Health, Guy's and St Thomas' NHS

Foundation Trust, London, UK

${ }^{15}$ Patient research partner, Duisburg, Germany

${ }^{16}$ Department of Obstetrics and Gynaecology, Inselspital University Hospital Bern, Bern, Switzerland

${ }^{17}$ Rheumatology Department, Hospital Universitario de la Princesa, Madrid, Spain

${ }^{18}$ Dipartimento di Malattie Rare, Immunologiche, Ematologiche ed

Immunoematologiche. Centro di Ricerche di Immunopatologia e Documentazione su

Malattie Rare (CMID). Struttura Complessa a Direzione Universitaria di Immunologia

Clinica, Ospedale Torino Nord Emergenza San G. Bosco ed Università di Torino,

Torino, Italy

${ }^{19}$ Institute of Neuromedicine and Movement Science, Faculty of Medicine and Health Sciences, NTNU, Norwegian University of Science and Technology, Trondheim, Norway

${ }^{20}$ Norwegian National Advisory Unit on Pregnancy and Rheumatic Diseases, Dept of Rheumatology, St Olavs Hospital University Hospital in Trondheim, Trondheim, Norway

Correction notice This article has been corrected since it published Online First. The first author statement has been added.

Twitter Laura Andreoli @lauraandreoli80, Diederik De Cock @DiederikDeCock, Anna Molto@annamolto, Catherine Nelson-Piercy @nelson_piercy and Sebastian Cruz Rodríguez-García @sdlcrodriguez

Acknowledgements The authors would like to thank all contributing experts who participated in the Delphi online survey: Peer Aries; Sebnem Ataman; Irene Bultink; Marion Couderc; Diana Dan; David d'Cruz; Jip de Vries; Thomas Dörner; Lene Dreyer; Aline Frazier; Ruth Fritsch-Stork; James Galloway; Ian Giles; Cornelia Glaser; Gaelle Guettrot-Imbert; Isabell Haase; Karin Hellgren; Jörg Henes; Merete Hetland; Kimme Hyrich; Synøve Kalstad; Emese Kiss; Estibaliz Lazaro; Véronique le Guern; HannsMartin Lorenz; Juan Antonio Martínez López; Monika Oestensen; Øyvind Palm; Jose Maria Pego-Reigosa; Antonia Puchner; Klara Rosta; Guillermo Ruiz-Irastorza; Christof Schaefer; Matthias Schneider; Carina Skorpen; Susanna Späthling-Mestekemper; Christof Specker; Tone Størseth Moksnes; Bjørg Tilde Svanes Fevang; Antonio Szanto; Gabriella Szucs; Tunde Tarr; Angela Tincani; Ines von Mühlenen; Anne Voss; Corinna Weber-Schoendorfer; Jakub Zavada.

Collaborators Peer Aries; Sebnem Ataman; Irene Bultink; Marion Couderc; Diana Dan; David d'Cruz; Jip de Vries; Thomas Dörner; Lene Dreyer;Aline Frazier; Ruth Fritsch-Stork; James Galloway; Ian Giles; Cornelia Glaser; Gaelle Guettrot-Imbert; Isabell Haase; Karin Hellgren; Jörg Henes; Merete Hetland; Kimme Hyrich; Synøve Kalstad; Emese Kiss; Estibaliz Lazaro; Véronique le Guern; Hanns-Martin Lorenz; Juan Antonio Martínez López; Monika Oestensen; Øyvind Palm; Jose Maria Pego-Reigosa; Antonia Puchner; Klara Rosta; Guillermo Ruiz-Irastorza; Christof Schaefer; Matthias Schneider; Carina Skorpen; Susanna Späthling -Mestekemper; Christof Specker; Tone Størseth Moksnes; Bjørg Tilde Svanes Fevang; Antonio Szanto; Gabriella Szucs; Tunde Tarr; Angela Tincani; Ines von Mühlenen; Anne Voss; Corinna Weber-Schoendorfer; Jakub Zavada.

Contributors All authors listed fulfil authorship criteria. They have contributed to the task force and have been engaged in the design of the work, attended meetings, were involved in drafting the manuscript and approved the final version.

Funding This work was supported by EULAR and received a research grant from FOREUM Foundation in Rheumatology.

Competing interests AM: speaker/consultant fees: Abbvie, BMS, MSD, Novartis, Pfizer, UCB; unrestricted grants: Pfizer and UCBAS: speaker fees: AbbVie, BMS, MSD, Novartis, Pfizer, Roche, Sanofi Aventis, UCBA Zbinden: none. AZink: speaker fees from AbbVie, Janssen, Pfizer, Roche and Sanofi-Aventis. CN-P: consultancy fees from UCB and Alliance Pharma. Speaker fees from UCB, Alliance Pharma, Alexion, Sanofi, Falk, Janssen. DDC: none. DG: none. FF: consultant for UCB, GSK, Roche. Speakers bureau: UCB, GSK. Research grants from UCBLA: speaker/consultant fees: GSK, Novartis, UCB, Eli Lilly, INOVA Diagnostics/Werfen Group. LR: none. MW: none. NC-C: no personal fees. Research grants from UCBRD: received an unrestricted research grant form UCB Pharma BV and from the Dutch Arthritis Association a non-commercial fund raising organisation. RFB: speaker/consultant fees: Abbvie, Biogen, BMS, Celgene, Chugai, GSK, Janssen, Lilly, Medac, MSD, Novartis, Roche, UCBRÖ: None. SCR-G: speaker fees from Sanofi, MSD, UCB, Novartis and Janssen. SS: none. YM: lecture honoraria from Pfizer.

Patient and public involvement Patients and/or the public were involved in the design, or conduct, or reporting, or dissemination plans of this research. Refer to the Methods section for further details.

Patient consent for publication Not required.

Ethics approval Full information about the study was given when inviting potential participants via email as well as on the website of the Delphi survey. Prerequisite for participation in the survey was a registration in the Delphi Manager system, which was considered to imply consent.

Provenance and peer review Not commissioned; externally peer reviewed. 
Open access This is an open access article distributed in accordance with the Creative Commons Attribution Non Commercial (CC BY-NC 4.0) license, which permits others to distribute, remix, adapt, build upon this work non-commercially, and license their derivative works on different terms, provided the original work is properly cited, appropriate credit is given, any changes made indicated, and the use is non-commercial. See: http://creativecommons.org/licenses/by-nc/4.0/.

\section{ORCID iDs}

Yvette Meissner http://orcid.org/0000-0003-0147-4112

Laura Andreoli http://orcid.org/0000-0002-9107-3218

Nathalie Costedoat-Chalumeau http://orcid.org/0000-0002-1555-9021

Anna Molto http://orcid.org/0000-0003-2246-1986

Sebastian Cruz Rodríguez-García http://orcid.org/0000-0002-7773-151X

Savino Sciascia http://orcid.org/0000-0003-1266-9441

Anja Strangfeld http://orcid.org/0000-0002-6233-022X

\section{REFERENCES}

1 Götestam Skorpen C, Hoeltzenbein M, Tincani A, et al. The EULAR points to consider for use of antirheumatic drugs before pregnancy, and during pregnancy and lactation. Ann Rheum Dis 2016;75:795-810.

2 Meissner Y, Strangfeld A, Costedoat-Chalumeau N, et al. European Network of Pregnancy Registers in Rheumatology (EuNeP) —an overview of procedures and data collection. Arthritis Res Ther 2019;21:241.

3 Radner H, Chatzidionysiou K, Nikiphorou E, et al. 2017 EULAR recommendations for a core data set to support observational research and clinical care in rheumatoid arthritis. Ann Rheum Dis 2018;77:476-9.

$4 \mathrm{McCann}$ LJ, Pilkington CA, Huber AM, et al. Development of a consensus core dataset in juvenile dermatomyositis for clinical use to inform research. Ann Rheum Dis 2018:77:241-50.

5 Ehlers L, Askling J, Bijlsma HW, et al. 2018 EULAR recommendations for a core data set to support observational research and clinical care in giant cell arteritis. Ann Rheum Dis 2019;78:1160-6.

6 Chatzidionysiou K, Hetland ML, Frisell T, et al. Opportunities and challenges for real-world studies on chronic inflammatory joint diseases through data enrichment and collaboration between national registers: the Nordic example. RMD Open 2018:4:e000655.

7 van der Heijde D, Aletaha D, Carmona L, et al. 2014 update of the EULAR standardised operating procedures for EULAR-endorsed recommendations. Ann Rheum Dis 2015;74:8-13.

8 Kirkham JJ, Davis K, Altman DG, et al. Core outcome Set-STAndards for development: the COS-STAD recommendations. PLoS Med 2017;14:e1002447.
9 Guyatt GH, Oxman AD, Vist GE, et al. Grade: an emerging consensus on rating quality of evidence and strength of recommendations. BMJ 2008;336:924-6.

10 Boers M, Kirwan JR, Tugwell P, et al. The OMERACT Handbook, 2018.

11 Task Force on Research Specific to Pregnant Women and Lactating Women (PRGLAC). Report to Secretary, health and human services Congress, 2018. Available: https:// www.nichd.nih.gov/sites/default/files/2018-09/PRGLAC_Report.pdf [Accessed 16/11/18]

12 Giovannopoulou E, Gkasdaris G, Kapetanakis S, et al. And pregnancy: a literature review. Curr Rheumatol Rev 2017;13:162-9.

13 Andreoli L, Gerardi MC, Fernandes M, et al. Disease activity assessment of rheumatic diseases during pregnancy: a comprehensive review of indices used in clinical studies. Autoimmun Rev 2019;18:164-76.

14 Schaefer C, Ornoy A, Clementi M, et al. Using observational cohort data for studying drug effects on pregnancy outcome--methodological considerations. Reprod Toxicol 2008;26:36-41.

15 Østensen M, Andreoli L, Brucato A, et al. State of the art: reproduction and pregnancy in rheumatic diseases. Autoimmun Rev 2015;14:376-86.

16 Vinet E, Chakravarty EF, Clowse MEB. Power in numbers. Rheumatology 2018;57:v40-7.

17 Duffy J, Rolph R, Gale C, et al. Core outcome sets in women's and newborn health: a systematic review. BJOG 2017;124:1481-9.

18 Curtis JR, Jain A, Askling J, et al. A comparison of patient characteristics and outcomes in selected European and U.S. rheumatoid arthritis registries. Semin Arthritis Rheum 2010;40:2-14

19 Putrik P, Ramiro S, Kvien TK, et al. Inequities in access to biologic and synthetic DMARDs across 46 European countries. Ann Rheum Dis 2014;73:198-206.

20 Phipps E, Prasanna D, Brima W, et al. Preeclampsia: updates in pathogenesis, definitions, and guidelines. Clin J Am Soc Nephrol 2016;11:1102-13.

21 Abalos E, Cuesta C, Grosso AL, et al. Global and regional estimates of preeclampsia and eclampsia: a systematic review. Eur J Obstet Gynecol Reprod Biol 2013;170:1-7.

22 Chiarotto A, Ostelo RW, Turk DC, et al. Core outcome sets for research and clinical practice. Braz J Phys Ther 2017;21:77-84.

23 Williamson PR, Altman DG, Blazeby JM, et al. Developing core outcome sets for clinical trials: issues to consider. Trials 2012;13:132.

24 Sinha IP, Smyth RL, Williamson PR. Using the Delphi technique to determine which outcomes to measure in clinical trials: recommendations for the future based on a systematic review of existing studies. PLoS Med 2011;8:e1000393.

25 ICH Guideline. Clinical safety data management: definitions and standards for expedited reporting E2A, 2020. Available: https://database.ich.org/sites/default/files/ E2A_Guideline.pdf [Accessed 11/08/2020]. 